\title{
RECORD OF WHITE WING-BARRING IN COMMON CROW
}

by Spencer Sealy, Department of Zoology, University of British Columbia, Vancouver 8, B.C.

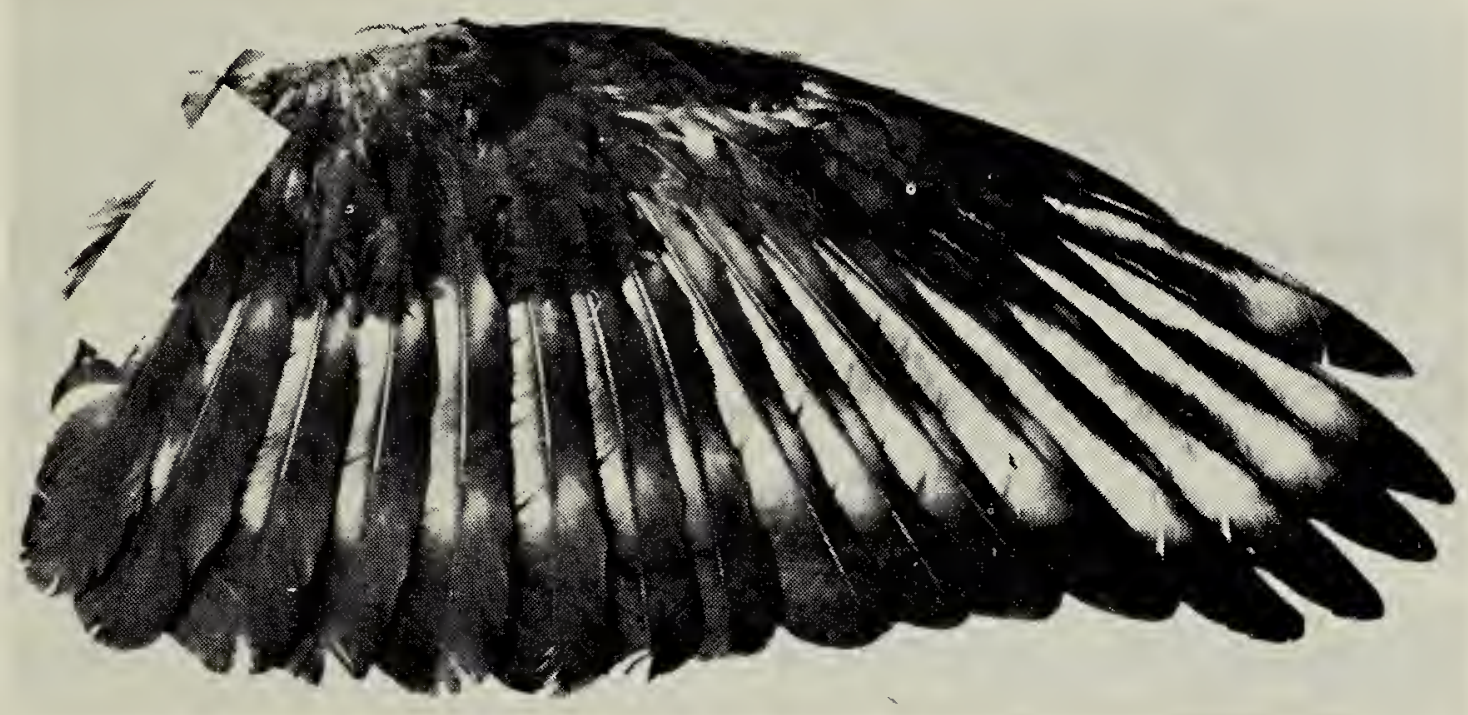

Figure 1. Right wing of Common Crow (U.B.C.M.Z. No. 13296) showing white wing markings in the primaries, secondaries and greater primary coverts.

Several years ago I had occasion to bserve white wing-barring in the Common Crow (Corvus brachyrhynchos). This phenomenon has recently been reported by Short and Laybourne, 1967, Wilson Bull., 79:113-114. Their two records of white wing markings in the Common Crow, one a sight record and one a specimen, were obtained near Rockville, Montgomery County, Maryland, on October 2, 1965. Having read Short and Laybourne's article, with its discussion of the possible causes of white wing markings in crows, I should like to report another instance of this phenomenon, observed in Saskatchewan.

On August 25, 1962, two miles south of Battleford, Saskatchewan, a male Common Crow with white wing markings was observed and subsequently collected. The bird, an immature as indicated by its worn primaries (Emlen, 1936. Condor, 38:99-102) was not prepared as a study skin, but the right wing was removed, spread, and dried (U.B.C. Mus. Zool. No. 13296). Except for white in the remiges and greater primary coverts of both wings, it was normal in colour throughout. The white markings were similar and symmetrical in both wings. The specimen described by Short and Laybourne (op. cit.), also an immature, was similarly marked except that it did not exhibit white in the greater primary coverts. On the Battleford specimen white occurs mainly on the inner vane of primaries 1 to 10 , secondaries 1 to 8 , and about equally on each vane of greater primary coverts 1 to 8 (Figure $1)$. The outer vane of primaries 1 to 3 and secondaries 1 to 5 show small white patches near the base and at a point about three-fourths down the length of the feathers; the outer vane of primaries 4 to 9 exhibit white along the rhachis over the middle half of the feathers (Figure 1). Secondaries 6 and 7 show small white patches at the base of the feathers in the outer vane. The white on the outer primaries 5 to 8 is longer relative to that on the other primaries and the secondaries; however, in general (as in the Maryland specimen) the overall white pattern in the wing is that of an interrupted broad bar, which is visible when the wing is spread. 